\title{
THE IMPORTANCE OF WORD ORDER IN EXPLAINING TONE PATTERNS IN AVOKAYA VERBS
}

\author{
Eileen Kilpatrick \& Leoma Gilley \\ SIL International
}

\begin{abstract}
This paper presents a set of ordered rules accounting for tone changes that occur in Avokaya verbs. The most prevalent shape for Avokaya verbs is monosyllabic. Disyllabic verbs roots behave the same way as disyllabic verbs which are composed of a derivational prefix plus a monosyllabic verb root. The derivational prefixation process is the same for verbs in all grammatical constructions. Verbs in SVO constructions and SOV constructions are treated separately, since different rules apply for these two sets of constructions. Avokaya syllables may carry a high, mid, low or rising tone, but not a falling tone. In this analysis of Avokaya, we show that the expected HL tone pattern has merged to form a $\mathrm{M}$ tone in the verbal system.
\end{abstract}

\section{Introduction.}

Avokaya belongs to the Moru-Ma'di sub-group of the Central Sudanic language family, a branch of the Nilo-Saharan family. The dialect of Avokaya used in this paper is spoken in southern Sudan. The data for this paper were gathered over approximately 23 years of work in the language. This paper provides a principled account of tonal alternations in the verbs in Avokaya.

Avokaya has a seven vowel system, three Advanced Tongue Root

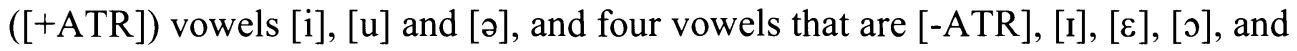
[a]. Vowel harmony causes a [-ATR] vowel in a verb prefix to assimilate to the corresponding [+ATR] vowel (Callinan 1981). The nominal system of Avokaya demonstrates three level tone patterns, High, Mid and Low. In addition, there is a Rising contour on short vowels, but no Falling contour on short vowels. Phonetically a Falling or Rising contour may occur on long vowels, but these long vow- 
els are considered sequences of two Tone Bearing Units (TBU). ${ }^{1}$ There are only a few examples of vowel sequences in Avokaya with either contour tones or level tones.

In the nominal system, there are no restrictions on the occurrence of the three level tones, as shown by the representative examples below.

(1) Monosyllabic nouns

\begin{tabular}{|c|c|c|}
\hline $\mathrm{H}$ & $\mathrm{M}$ & \\
\hline
\end{tabular}

(2) Disyllabic nouns

\begin{tabular}{|c|c|c|c|c|}
\hline $\begin{array}{l}\mathrm{HH} \\
\text { Ídrí 'vein' }\end{array}$ & $\begin{array}{l}\text { HM } \\
\text { Ír̄ }\end{array}$ & 'eagle' & $\begin{array}{l}\text { HL } \\
\text { Ínà }\end{array}$ & 'crocodile' \\
\hline $\begin{array}{l}\text { MH } \\
\text { İmbá 'net' }\end{array}$ & $\begin{array}{l}\text { MM } \\
\bar{\jmath} z \bar{\varepsilon}\end{array}$ & 'rain' & $\begin{array}{l}\text { ML } \\
\text { indrì }\end{array}$ & 'child minder' \\
\hline 'millet' & $\begin{array}{l}\text { LM } \\
\text { ilì }\end{array}$ & 'wind' & $\begin{array}{l}\text { LL } \\
\text { ìzà }\end{array}$ & 'sadness' \\
\hline
\end{tabular}

A rising tone can occur on monosyllabic nouns.
fว 'flower'
Š
'hail'

In multisyllabic nouns a rising tone occurs only on the first syllable of disyllabic nouns with a monosyllabic root.

${ }^{1}$ The following abbreviations are used in this paper: $2 \mathrm{~S}$ second person singular, $3 \mathrm{~S}$ third person singular, $\mathbf{3}^{\text {rd }}$ IMP third person imperative, conj conjunction, DIR direction toward speaker (ventive), dpfx derivational prefix, EOC end of embedded construction, $\mathbf{H}$ high tone, IMP imperative, INFIN infinitive, $\mathbf{L}$ low tone, $\mathbf{M}$ mid tone, neg negation, O-FOC focus on object, PERF perfective aspect, PURP purpose marker, $\mathbf{R}$ rising tone, $\mathbf{S M}$ subject marker for sequential action and relative clauses, SEQ verb marker for sequential action, S-FOC focus on subject, sfx suffix, vbrt verb root. 

(4) y̌̃-wá
'fly type'2

Rising tone also occurs on the first syllable of multisyllabic multi-morphemic nouns with syllabic reduplication.
đ̌̃ đī -yá
'bird type'
đǔdū-wá
'headache type'

Since contour tones on short vowels are restricted to initial syllables, this could be analyzed as right-to-left association of tone, but in-depth discussion of this is beyond the scope of this paper.

There are contour tones on phonetically long vowels, analyzed as vowel sequences, in Avokaya nouns as follows.
(6)

$\begin{array}{ll}\text { dí } & \text { 'person' } \\ \text { ràtáà } & \text { 'chant' } \\ \text { gìnírí } & \text { 'mosquito' }\end{array}$
(High-Mid)
(High-Low)
(Low-High)

By way of contrast, the tone patterns of Avokaya verbs have shown some interesting restrictions. There are only four tone patterns in evidence. ${ }^{3}$

$\begin{array}{llll}\text { Class 1 } & \text { Class 1A } & \text { Class 2 } & \text { Class 2A } \\ \text { Mid } & \text { Mid-Mid } & \text { Low } & \text { Mid-Low } \\ \text { că }^{-4} \text { 'arrive' } & \bar{a} \bar{j} \text { 'accompany' } & \text { nì 'go' } & \text { àtì 'lean (against)' }\end{array}$

${ }^{2}$ A group of multisyllabic verbs derive from nouns. These verbs, which are not within the scope of this paper, have regular surface tone patterns of Mid High (High) (High) Low, e.g. İbádík̀ 'tie around (something)', íbábátzà 'baptize' The first syllable is a derivational prefix with preassigned HL tone. The verb root has a HL melody. The tone changes in the various verb forms of this class of verbs are similar to the changes in the Mid-Low verb class.

${ }^{3}$ There are a group of multisyllabic verbs derived from nouns. These verbs, which are not within the scope of this paper, have regular surface tone patterns of Mid High (High High) Low. The first syllable is a derivational prefix with preassigned HL tone. The verb root has a HL melody. The tone changes in the various verb forms of this class of verbs are similar to the changes in the Mid-Low verb class.

${ }^{4}$ The symbol $c$ represents a phoneme that alternates between [ts] and [t $\left.f\right]$ depending on context, and the symbol $j$ represents a phoneme that alternates between $[\mathrm{dz}]$ and $\left[\mathrm{d}_{3}\right]$ depending on context. 
Class 1 and Class 2 are always monosyllabic verbs. Class 1A and Class 2A are always disyllabic verbs. Traditionally the verbal system has been viewed as having four verb classes (Callinan 1986). Analyses of the verbal system of other Moru-Ma'di languages are based on tone without determining whether some verb classes could be derived from others (Wright 1995, Andersen 1984).

To date, there has been no attempt to provide an analysis of the verb system of Avokaya that accounts for all the tonal changes evident in the data. A full listing of those changes is found in example (1). Each structure listed will be handled separately.

Class 1 Class 1A

Class 2 Class $2 A$

nì

a. cā

àjī

b. cá-lé b $\bar{\varepsilon}^{-6} \quad \bar{a}$ jí-lí be

c. cá kj̄ àjí kj

(S)OV constructions

d. cà -zó àjí-zó

e. cǎ

ājí

f. cà kā

$\bar{a} \mathrm{j} \overline{\mathrm{k}} \mathrm{a}$

g. cà cà $\bar{a} \mathbf{j} \overline{\mathrm{a}} \mathrm{j} \mathbf{i}$ 'arrive' nì-zó ว̄t̀̀-zó

nั $\quad \bar{t} \check{t}$

nì kā àtì kā

nì nì ātì ว̄tı̀

'go' 'lean'
Morphological

Structure

citation form $^{5}$

(imp.: 3.1)

when (tail-

head linkage: 3.2 )

neg. statement: 3.3

Looking down the columns, it is clear that there are significant tonal changes from construction to construction, especially in the Class 1 verbs.

${ }^{5}$ There are no uninflected forms of the verb in Avokaya. Therefore the underlying form for verbs in classes 1 and $1 \mathrm{~A}$ cannot stand alone. The imperative has been used as the citation form since it has no affixes containing segmental phonemes. The resulting mid tone in this form is explained in section 3.1.

${ }^{6}$ Both this and the infinitive suffix, also $-l \dot{\varepsilon}$, are manifested as $-l_{i}$ after the [-ATR] vowel $I$, and as $-l i$ after the [+ATR] vowels $u$ and $i$. See section 3.1.1 for the discussion of this tail-head linkage construction. 
In this paper, we show that Avokaya has two basic tone classes of verbs, and that the forms found in $1 \mathrm{~A}$ and $2 \mathrm{~A}$ are subsets of those basic tone classes. When a derivational prefix is added to a verb root, the resulting verb has the same tone patterns as the verb forms found in Classes $1 \mathrm{~A}$ and $2 \mathrm{~A}$. In this case, the derivational prefix does not change the verb to a different word class, but changes the syllable structure of the verb, resulting in tone patterns distinct from the monosyllabic verb roots. A series of rules are presented that account for all the tonal changes which occur in the verbal system.

This analysis assumes that the underlying tones of the verb roots are either High or Low. However, it should be noted that the underlying High tone form never occurs in isolation in the monosyllabic verbs. The Low tone verbs do not present as much of a problem, but the tone changes in the High tone verbs are of particular interest since the High tone monosyllabic verbs often surface as having a Mid tone. It is assumed that there is an additional Low tone morpheme that results in a lowering of the surface tone from High to Mid. This morpheme is discussed in section 3.1.

As is often the case, derivational affixes are added to a root before inflectional ones. Also, derivational affixes may have a more extensive effect on the word than inflectional affixes do. It is assumed in this analysis that any derivational affixation will be completed before any inflectional affixation. ${ }^{7}$ The order of the nuclear constituents of a clause determines the tonal pattern of verbs in some contructions. The underlying word order is SVO, but there are certain constructions that have an SOV order. First, we will discuss underlying tone, then the tones of verbs in the SVO order, and finally the tones of verbs in the SOV order.

\section{Underlying Tones.}

Two lexical tone classes are posited for (monosyllabic) verb roots in Avokaya. In the first class, a High tone is posited as the underlying tone while the second class has a Low pattern. There is a disyllabic subset of verbs within each of these two classes. (Historically the disyllabic verbs were composed of a derivational prefix plus monosyllabic verb root.) When a derivational prefix (which is always Mid toned) is added to the High tone monosyllabic verb roots of Class 1, the behavior

\footnotetext{
${ }^{7}$ In fact, if a derivational prefix were to be added after the application of the rules affecting tone changes in the verb, an ungrammatical form would result. For instance, if the directional prefix $\bar{a}$ - were to be added to the root cá 'arrive' after the rules of level 2 were applied, the following ungrammatical forms would result: *ācàlé 'to arrive here', *āča '(lest...) arrive'.
} 
of the new verb stems is identical to the verbs of Class 1A. Also the derivational prefix added to the monosyllabic verb roots of Class 2 behave like the verbs of Class 2A. Therefore the disyllabic verbs of Class $1 \mathrm{~A}$ are assumed to have the underlying tone pattern Mid High, while those of Class $2 \mathrm{~A}$ have the underlying tone pattern of Mid Low.

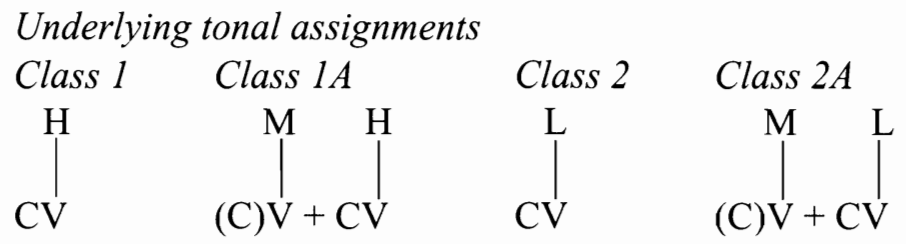

1.1 Derivational prefixes. There are various derivational verb prefixes which, when added to verbs, form new verb stems. Examples of these prefixes are given below. These prefixes differ from inflectional prefixes in that their addition results in a disyllabic verb with all the tone changes that disyllabic verb stems have. Inflectional prefixes, on the other hand, do not affect the tone of the verb root.

The derivational prefixes that can be added to Avokaya verbs are as follows. The first is "direction toward speaker" (ventive) $\bar{a}-.{ }^{8}$
(10) cā 'arrive (there)'
$\overline{\mathrm{a}}-\mathrm{c} \overline{\mathrm{a}}$
'arrive (here)'
nì 'go'
à-nì
'come'

This prefix is highly productive. The second is the multiplicative, denoting multiple action or participants, $\bar{\jmath}-$ or $l \overline{5}-{ }^{9}$ depending on the specific verb.
(11) fū 'kill'
$\overline{\mathrm{u}}-\mathrm{fu}$
'kill (many)'
bà 'put, make'
15-6à
'make (many things)'

This prefix is also highly productive. The third is the transitivizer, $\overline{5}_{-}, \overline{5}_{-}^{-},{ }^{10}$ or $\mathrm{V}_{1^{-}}$ depending on the specific verbs, where $V_{1}$ is a mid toned vowel matching the features of the root vowel.

\footnotetext{
${ }^{8}$ This prefix is manifested as $\bar{\partial}$ - before verb roots with [+ATR] vowels and as $\bar{a}$ - $e$ lsewhere.

${ }^{9}$ In both cases, the prefix $\bar{\nu}$ - is manifested as $\bar{u}$ - before verbs with [+ATR] vowels and $\bar{j}$ - elsewhere.

${ }^{10}$ The prefix $l \bar{\nu}$ - is manifested as $l \bar{u}$ - before verb roots with [+ATR] vowels.
} 
(12)
a. rā 'run'
j - rā 'strain (liquid) out'
b fi 'enter'
$1 \overline{0}$ - fi 'bring (something) in'
c. fò
'exit'
$15-$ fo
'take out (of a house)'
d. drā
'bubble/parboil'
à- drā
'parboil (something)'
e. $\operatorname{tr} \bar{\varepsilon}$
'shout/make noise'
$\bar{\varepsilon}-\operatorname{tr} \bar{\varepsilon}$
'clear (throat)'
f. $c \overline{\mathrm{I}}$
'be lit'
I- cì
'light (fire)'

This type of prefix is fairly productive.

For each derivational prefix the prefix tone surfaces as a Mid tone. There are also restrictions as to which derivational prefixes can be added to which verb roots. For instance, intransitive motion verbs can take a directional prefix, but not the prefix denoting multiple action.

Verbs in Class 1 are monosyllabic verbs with a High tone root, and Class 2 are monosyllabic verbs with a Low tone root. These are the two basic verb classes. Verb Classes 1A, disyllabic verbs with $\mathrm{MH}$ tone pattern, and 2A, disyllabic verbs with ML tone pattern, are linked to Class 1 and Class 2 respectively, since disyllabic verbs stems derived from the monosyllabic verb roots of Class 1 act exactly like verb roots of Class $1 \mathrm{~A}$, and disyllabic verb stems derived from the monosyllabic verb roots of Class 2 act exactly like the verb roots of Class $2 \mathrm{~A}$. The same tone changes occur in the corresponding grammatical constructions. Compare the tone patterns of the monosyllabic verb roots of Class 1 and 2 in (13) below having the added directional prefix $\bar{a}-$, with the verbs of Class $1 \mathrm{~A}$ and $2 \mathrm{~A}$. 
(13)

\begin{tabular}{|c|c|c|}
\hline Prefixed & Class $1 A$ & $\begin{array}{l}\text { Prefixed } \\
\text { Class } 2\end{array}$ \\
\hline$M H$ & $M H$ & $M L$ \\
\hline $\begin{array}{l}\text { 'arrive } \\
\text { (here)' }\end{array}$ & 'accompany' & 'come' \\
\hline
\end{tabular}

a. $\bar{a}-c \bar{a}$

$\bar{a} \bar{j} \bar{I}$

ā- nì

ว̀t

citation (imp.)

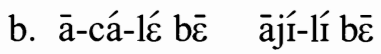

ā-nì-lí be $\quad \bar{\partial}$ tì $-l_{1} b \bar{\varepsilon}$

when (tail-head

'when.. 'when...

'when... 'when...

arrived' accompanied' came' leaned'

c.

à-cá ko ajı ko

ā- nì kj̄ ātî́ kō

'did not 'did not come' lean' arrive'

'did not accompany'

d.

ā-nì-zó

'came'

ā-ñ

'(lest)... come'

àtì-zó

'leaned'

aspect/mode

e. ̄a-cá

àjí

'(lest)...

'(lest).. arrive' accompany'

f. $\bar{a}-c \bar{a} k \bar{a}$ 'of àjí kā

'of

ā-nì kā 'of arriving'

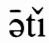

'(lest)... lean'

òtı̀ kā 'of leaning' g. ā-cā ā-cā àjī àjī 'arriving' 'accompanying' inflection

negative statement

S conj.

$\mathrm{O} \mathrm{V}$

genitive

participle

\footnotetext{
${ }^{11}$ Tail-head linkage is a means of slowing down the action of a discourse. Information of a previous clause is repeated in a when-clause introducing the next sentence. An example would be 'John went to town. When he went, he met an old man on the way. When he met the old man, the man asked him for a ride.' In Avokaya this is a grammatical construction that is distinct from other temporal clauses.
} 
At level I, prefixed verbs of Class 1 become Class $1 \mathrm{~A}$ verbs, and prefixed verbs of Class 2 become Class $2 \mathrm{~A}$ verbs.

1.2 Patterns for the initial syllable of a disyllabic verb. The only four patterns for the initial syllable of a disyllabic verb are as follows. ${ }^{12}$ The most common initial syllable of a disyllabic verb is $\bar{a}$ - and its [+ATR] equivalent, $\bar{\partial}$ - (see (8)).
(14) $\bar{a} j \bar{\jmath}$
'accompany'
ว̀tì 'lean'

The prefixes $\bar{I}$-, and $\bar{j}$ - are equally possible and can occur on verbs regardless of the vowel of the verb root.
(15) İcā
'be able'
כ̄pi $\quad$ 'shell (peanuts)'

There are also disyllabic vowel initial verbs where the same vowel occurs in both the first and second syllables.
(16) $\bar{\varepsilon} \mathrm{d} \bar{\varepsilon}$
'prepare'
ijj̄ 'ask'
ùgù
'steal'
ipì 'press down'

The first syllable of disyllabic verbs may also be $l_{\bar{b}}-, l_{\bar{a}}$, or $l_{I-}$.
(17) $1 \overline{\mathrm{p}} \bar{\varepsilon}$
'extend'
lāvì 'play'
lî̉ā
'creep'

The first syllables of all disyllabic verbs in Avokaya are restricted to these forms, which are similar to the forms of known derivational prefixes.

There are only a small number of disyllabic verbs which can take a recognized derivational prefix. ${ }^{13}$ To date, only two examples have been encountered in which a disyllabic verb takes the derivational prefix. In both cases, the initial vowel of the verb root is deleted when the derivational prefix is added.
(18) àjì 'accompany'
lōjī 'accompany many'
àtì 'lean'
lūtì 'support a leaning object'

The deletion of this initial root vowel is shown in the following rule.

\footnotetext{
12 There is no restriction to the inventory of phonemes that can occur in disyllabic nouns.

${ }^{13}$ All verbs can take inflectional prefixes.
} 
(19) Root Vowel Deletion Rule (RVD)

$$
\mathrm{V} \rightarrow \varnothing / \mathrm{V}_{-\mathrm{dpfx}} \mathrm{CV}_{\text {vbrt }}
$$

This vowel deletion does not occur when an inflectional prefix is added.

(20) á-àjī

'be accompanied' (agentless passive)

1.3 Derivational prefixation process. In light of the above examples, the process involved in adding derivational prefixes to the underlying form (UF) of a verb root is as follows.
(21) Class
Class $1 \mathrm{~A}$
Class 2
Class $2 A$
'arrive'
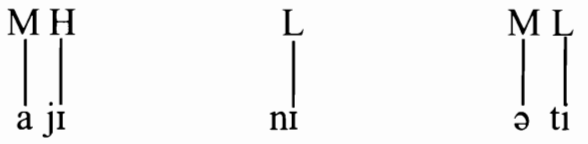
UF of root
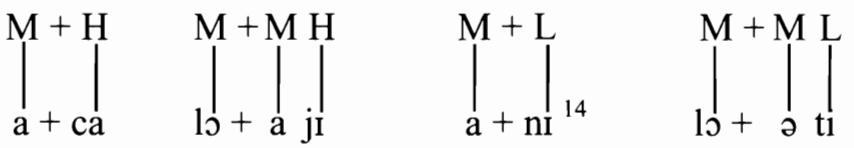
Prefixed form
(dir.)
(mult.)
(dir.)
(trans)

$\left.\right|_{b+t i} ^{M+L}$
$R V D$
[ācá]
'arrive
[1̄̄jí]
'accompany here'
[ānì]
'come
[lūti]
Uninflected form many'

Having given evidence for the underlying tones of the two basic classes of verbs and having demonstrated their similarities through derivational processes, the next section will demonstrate how the tone patterns shown in (8a-c) are derived.

${ }^{14}$ Different derivational prefixes are used in the examples due to semantic restrictions on which prefixes each verb can take. 


\section{Tonal Patterns For Verbs In SVO Constructions.}

In this section, SVO constructions will be considered. Initially there will be a discussion of the constructions using the citation form of the verb found in (8a). In each of these constructions there is a floating $L$ tone attached to the verb which accounts for the Mid tone pattern of Class 1 verbs and the Mid-Mid pattern of Class 1A verbs. This is followed by the dependency construction found in the 'when' clauses for tail-head linkage (example 8b). Finally, the negative statement verb form of example ( $8 \mathrm{c})$ will be discussed.

3.1 SVO constructions with floating low tone. There are a number of SVO constructions which have an inflectional suffix on the verb consisting of a floating Low tone. With the exception of the imperative clause, the constructions also have a particle that occurs later in the clause. These constructions include Perfective, with the particle trá; Focus constructions, with the particles $n \grave{I}$ or $T$; and, the Imperative construction. In these constructions, when the floating low tone is added, the $\mathrm{H}+\mathrm{L}$ combination results in a phonetic Mid tone. When the underlying tone is Low (as in Class 2 verbs), the $\mathrm{L}+\mathrm{L}$ combination does not change the surface form. Furthermore, this floating low tone does not result in downstep as in many African languages. The level of the High tone in trá is the same level as the High tone of má.

(22) Perfective
a. Imá cá ` trá/
[cā]
'I arrived'
I arrive PERF
b. /má àjí
gólā trál
[ājīi
'I accompanied him'
I accompany $3 \mathrm{~S}$ PERF
c. Imá nì ' trá/
[nì]
'I went'
d. /má ōtì 'gólā trá (f̄ rú)/
[ว̄ti]
'I leaned it (against a tree)'

(23) Focus
a. /má cá `nì/
I arrive S-FOC
b. /má ājí gólā ?ì/
[àjī]
'I am the one who arrived'
I accompany $3 \mathrm{~S}$ O-FOC
c. /má nì 'nì/
[ni] 'I am the one who went'
d. /má ōtì gólā nì/
[ว̄ti]
'he is the one I accompanied'
'I am the one who leaned it' 
(24) Imperative
a. /ní cá `/
[cā]
b. Iní àjí ‘gólā/
[âjì]
c. /ní nì ‘vólé /
[ni]
d. /ní ว̀tì gólā fề rú/
[ōtì]
'arrive (at a certain place)'
'accompany him'
'go away'
'lean it against a tree'

In the constructions in (22-24), there is a floating grammatical Low tone that comes after the verb root (as well as a particle that comes later in the clause to distinguish the clause type). This floating Low tone attaches to the verb root according to the Floating Tone Association rule shown in (25). It also coalesces with the High tone on the root of the Class 1 verbs to form a Mid tone according to the Tone Coalescence rule (26).

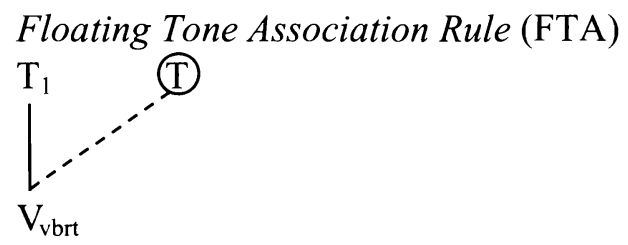

The Low tone morpheme is added to the underlying tone on the root vowel. In these constructions with a floating Low tone, there is coalescence of tone where a $\mathrm{HL}$ tone coalesces to a Mid tone.

(26) Tone Coalescence (TC)

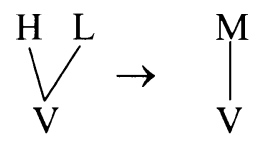

This rule accounts for certain Mid tones that exist in the surface level form in (2224). The result of this rule is a neutralization of tones; a HL sequence could give rise to a $\mathrm{M}$, as well as an underlying $/ \mathrm{M} /$ surfacing as a $\mathrm{M}$. This coalescence of $\mathrm{HL}$ into M explains why there are no falling tones on short vowels while there are rising tones. The output of these constructions was used as the "citation" form (tone patterns Mid, Mid-Mid, Low, and Mid-Low) of example (8a).

The following derivation of the Perfective, Focus and Imperative verb forms show how these rules apply. 
Class $1 \quad$ Class 1 A Class $2 A$
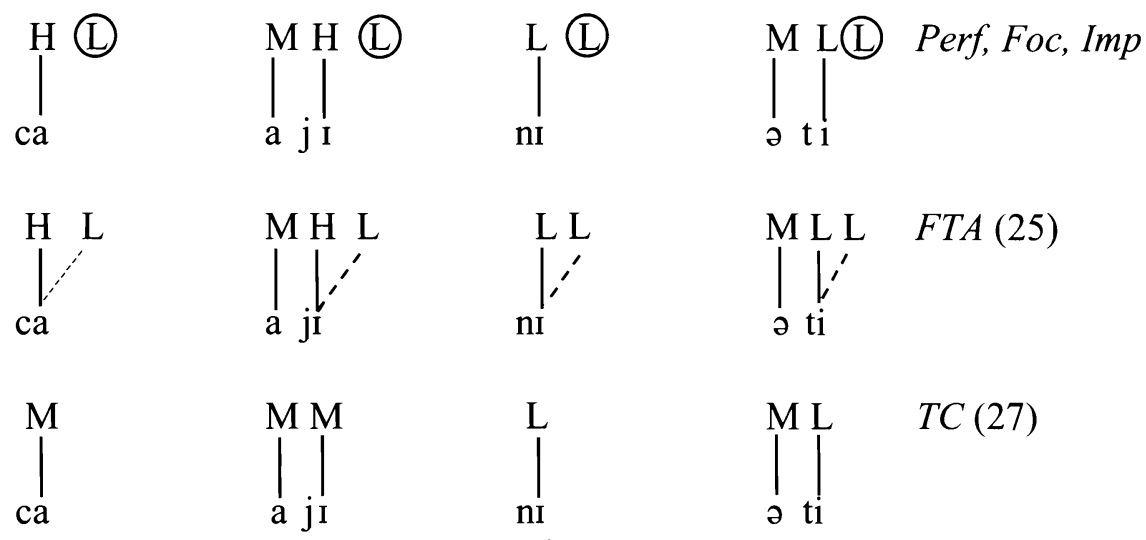

[cā]

[ā jīi

[ni]

'arrive'

'accompany' 'go'

[ว̈t̀]

'lean'

We assume that the grammatical Low tone merges with the Low tone of the melodies of the Class 2 verbs, in accordance with the Twin Sister Convention expounded by Clements and Keyser (1983).

3.2 'When' dependency construction. There is only one SVO construction where the verb stem takes a segmental inflectional suffix, the 'when' construction which repeats the action of the previous clause and takes the suffix $-l \bar{\varepsilon}$. The repeated verb provides tail-head linkage in order to slow down the progress of the narrative. This suffixed verb form ${ }^{15}$ undergoes no tone changes but keeps the underlying tone of the verb stem (see $8 b$ ). Consider the examples below.

$\mathrm{S} \quad \mathrm{V}$

a. (má ndrē ámā átá trá.) má ndré -lé bē ámā átá rī...

1S see my father PERF 1S see -when when my father EOC

'(I saw my father.) When I saw my father...'

b. má ājí -lí bē ámā átá rī...

1S accompany -when when my father EOC

'When I accompanied my father,..'

${ }^{15}$ There is also a form of this construction which has no segmental suffix. In that construction, the verb form has a floating low tone attached, like the constructions in section 3.1. 


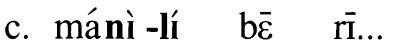

1S go -when when EOC

'When I went...'

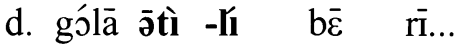
3S lean -when when EOC
'When he/it leaned...'

In each case, the verb stem retains the underlying tones.
(29) Class 1
Class $1 \mathrm{~A}$
Class 2
Class $2 A$
cá-lé
àjí-lí
nì-lí
àtì-
'when arrived'
'when accompanied'
'when went'
'when leaned'

The only change that occurs is in the vowel quality of $-l \varepsilon$, in that it harmonizes with the height of the previous vowel. Since the tone of the suffix $-l_{\varepsilon} \varepsilon$ is invariantly High, it is assumed that it bears a pre-assigned High tone.

The tone assignments for the verb of the dependency construction are:

(30)

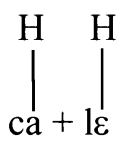

[cá-léc]

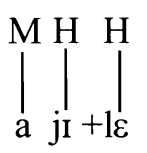

[ājí-líc]

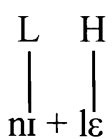

[nì-lí]

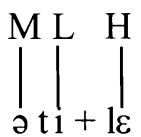

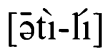

2.3 Negative statement. The final SVO verbal construction with distinct tone patterns is the Negative Statement (8c) with a negation morpheme on the verb as well as a negation word.

(31) Negative statement
a. gólā cá kō
'he did not arrive'
$3 \mathrm{~S}$ arrive not
b. gólā àjí mā k̄̄
'he did not accompany me'
3S accompany me not
c. gólā nì kjo
'he did not go'
d. gólā ว̄túı kō
'he did not lean' 
The negation morpheme on the verb is realized as a single empty $\mathrm{V}$ slot with $\mathrm{H}$ tone suffixed to the verb root. Since this $V$ is empty of all features except tone, it takes all other features from the final $\mathrm{V}$ of the verb stem. This is explained by the following Vowel Identity Rule, which is applied in this construction.

(32) Vowel Identity Rule (VI)

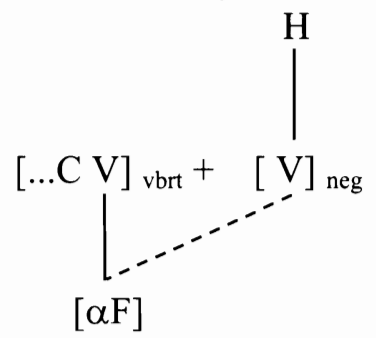

In this rule, the vowel features from the root, except for the tone, are spread to the empty set of features in the vowel slot of the suffix. The High tone is preassigned to the empty vowel slot. For verbs of Class 1 and $1 \mathrm{~A}$, a vowel reduction rule in also in effect.

The rules involved in producing the Negative Statement form of the verb are shown below.
(33)
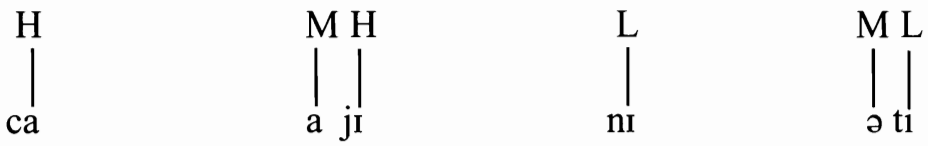
underlying
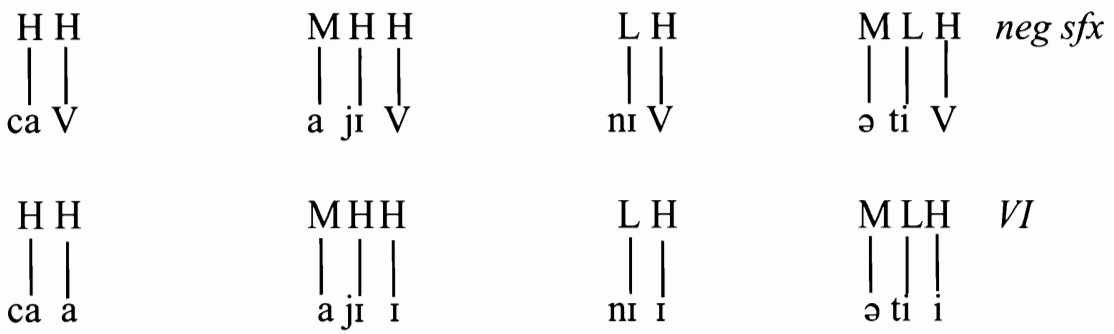
[cáá]
[äjı́'
[nัİ]
[ว̈tî́]

At the post-lexical level, there is a vowel reduction rule. If the vowel features including tone are identical and create a long vowel, then the vowel is shortened. If the tone is different, then the two vowels must be retained. 
(34) Vowel Reduction Rule (VR) ${ }^{16}$ v́v́ $\rightarrow$ v́

When the Vowel Reduction Rule is applied, the outcome (shown in (36)) has an identical surface form to the examples in $(8 \mathrm{c})$.
[cá]
[ājí
[nì]
[ว̄tî́]
'didn't arrive'
'didn't accompany'
'didn't go'
'didn't lean'

All of the tonal patterns for the verbs in SVO constructions have now been accounted for.

3.4 Inflectional prefixes on the verbs of SVO constructions. At this stage inflectional prefixes may be added to the verbs in SVO clauses. There are two inflectional prefixes in Avokaya: '́- indicates an agentless passive, and j- indicates irrealis. The agentless passive prefix can be added to the verb in any SVO construction. The irrealis prefix is used in conditional clauses, for indicating reported speech, and for indicating a third person imperative. These constructions have SVO word order with a floating Low tone on the verb like the constructions in Section 3.1. Both of these inflectional prefixes assimilate fully to the initial vowel of a vowel initial verb stem, and they assimilate to the vowel $u$ before consonant initial verb stems containing [+ATR] vowels. They remain $\supset$ before consonant initial verbs with [-ATR] vowels. Both of these prefixes may be added to a single verb stem. Neither one affects the tones of the verb stem.

In the example below, we represent each tone class by a transitive verb. The inflectional prefixes are added to the citation form of the verb (8). This citation form is used to indicate, among other things, perfective aspect or imperative mode.

\footnotetext{
${ }^{16}$ This rule applies only to vowels in verb roots/stems, as shown by such examples in other word classes as 'ifí 'for a long time', ymbàà 'open', fâà 'aimlessly'
} 
(36) Verb forms with inflectional prefixes

\begin{tabular}{|c|c|c|c|c|}
\hline $\begin{array}{l}\text { Class } 1 \\
\text { ndré } \\
\text { 'see' }\end{array}$ & $\begin{array}{l}\text { Class } 1 \mathrm{~A} \\
\text { àjí } \\
\text { 'accompany' }\end{array}$ & $\begin{array}{l}\text { Class } 2 \\
\text { bà } \\
\text { 'put' }\end{array}$ & $\begin{array}{l}\text { Class } 2 A \\
\text { àti } \\
\text { 'lean' }\end{array}$ & UF of verb \\
\hline ndre $\bar{\varepsilon}$ & $\bar{a} j \bar{I}$ & bà & àtı̀ & basic citation \\
\hline óndre & áāji & j́bà & ว́วิtì & Passive \\
\hline $\begin{array}{l}\text { 'he was } \\
\text { seen' }\end{array}$ & $\begin{array}{l}\text { 'he was } \\
\text { accompanied' }\end{array}$ & $\begin{array}{l}\text { 'it was } \\
\text { put' }\end{array}$ & $\begin{array}{l}\text { 'it was } \\
\text { leaned' }\end{array}$ & \\
\hline $\begin{array}{l}\text { gólā òndrē } \\
\text { 'let him } \\
\text { see' }\end{array}$ & $\begin{array}{l}\text { gólā ààjī } \\
\text { 'let him } \\
\text { accompany' }\end{array}$ & $\begin{array}{l}\text { gólā òbà } \\
\text { 'let him } \\
\text { put' }\end{array}$ & $\begin{array}{l}\text { gólā àāt̀̀ } \\
\text { 'let him } \\
\text { lean' }\end{array}$ & $3^{r d} I M P$ \\
\hline $\begin{array}{l}\text { óndrē } \\
\text { 'let it be } \\
\text { seen' }\end{array}$ & $\begin{array}{l}\text { áàājī } \\
\text { 'let him be } \\
\text { accompanied' }\end{array}$ & $\begin{array}{l}\text { óbà } \\
\text { 'let it be } \\
\text { put' }\end{array}$ & $\begin{array}{l}\text { ว́à̄̄ì } \\
\text { 'let it be } \\
\text { leaned' }\end{array}$ & both prefixes \\
\hline
\end{tabular}

Since the above prefixes do not affect the tone of the verb stem, no tone rules are necessary. In the last line of data of (36), note that a sequence of two vowels has a High Low sequence, not a Mid tone as would occur on a short vowel.

\section{SOV Tonal Patterns.}

There are certain grammatical constructions in which there is an SOV word order. The first of these includes constructions which have segmental inflectional suffixes for aspect or mode on the verb (see (8d)). An example of this type of construction is the sequential action construction used in procedural texts and to trace the event line in narrative texts.
(37) $\mathrm{S} \quad \mathrm{O} \quad \mathrm{V}$
gólā drí ámā sà -zó
'(next) he slapped me'
he SM me slap SEQ

The other construction occurs when certain subordinate conjunction constructions have an $\mathrm{S}$ conj $\mathrm{O} \mathrm{V}$ order (see also (8e)). 


\begin{tabular}{|c|c|c|c|c|}
\hline \multirow[t]{2}{*}{$\begin{array}{l}\mathrm{S} \\
\text { á́1 }\end{array}$} & $\begin{array}{l}\text { conj } \\
\text { jzó }\end{array}$ & $\begin{array}{l}\mathrm{O} \\
\text { ámā }\end{array}$ & 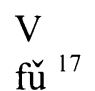 & ri \\
\hline & lest & me & kill & EOC \\
\hline
\end{tabular}

The two examples (37) and (38) have Class 1 verbs. The High tone Class 1 verb root has a Low tone in SOV constructions which have segmental inflections on the verb (37). The High tone Class 1 verb root has a rising tone in the $\mathrm{S}$ conj $\mathrm{O} \mathrm{V}$ constructions (38). To account for all tone changes in Class 1 verbs, it is proposed that monosyllabic verb roots of Class 1 and Class 2 undergo a second derivational process, that of tone replacement in these SOV constructions. This rule only applies to monosyllabic verb stems without derivational prefixes. The tone of the monosyllabic verb stem is replaced by a Low tone. ${ }^{18}$ For Class 1 verbs without derivational prefixes, High tone is replaced by Low tone. For Class 2 verbs the tone replacement results in a Low tone, since Low is replaced by Low. The tones of the remaining verb classes remain the same. This process applies after any derivational prefix is added. The addition of a derivational prefix produces a disyllabic verb stem which does not undergo the tone replacement derivation. Therefore the two derivational processes are ordered.

Tone Replacement Rule (TR)

$\mathrm{T} \rightarrow \mathrm{L} \quad$ for monosyllabic verb stems in $(\mathrm{S}) \mathrm{OV}$ constructions

The resulting tone assignments for verbs in SOV constructions are shown in (40).

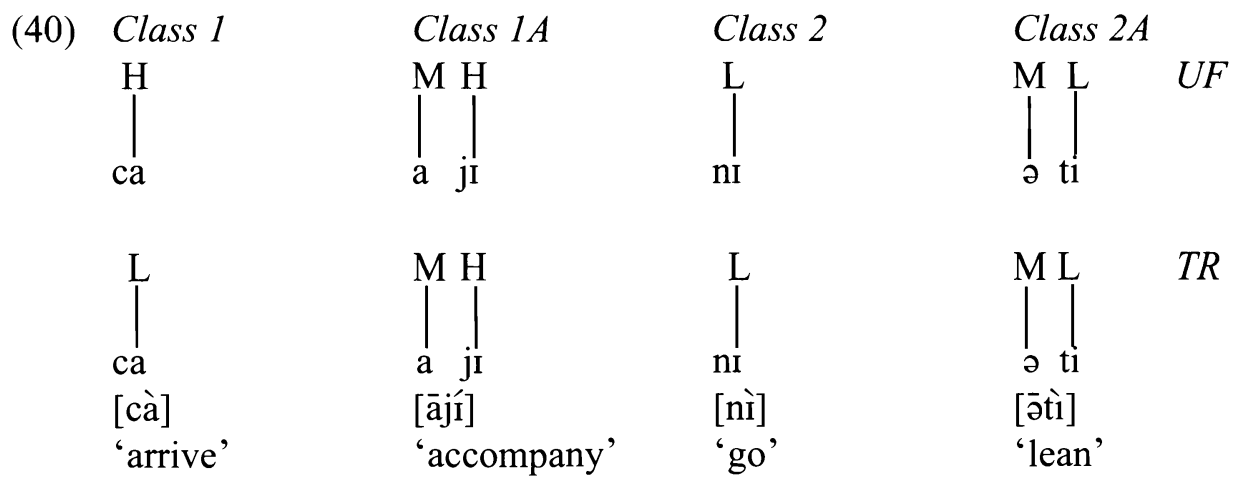

\footnotetext{
${ }^{17}$ The rising tone in this construction is explained in section 4.2.

${ }^{18}$ We would like to express our appreciation to Keith Snider for bringing to our attention the phenomenon of tone replacement.
} 
The SOV constructions are of two types, those with a segmental inflectional suffix on the verb, and those with a conjunction intervening between the Subject and Object ( $\mathrm{S}$ conj O V). Each of these two types have their own tone pattern, so will be treated separately in this paper.

4.1 SOV constructions with segmental inflectional suffixes. The possible verb suffixes for SOV constructions include - ?á 'imperfective', -zó 'sequential action, purpose', $-l \bar{\varepsilon}$ 'dependent/infinitive "to",' and -rì 'embedded dependent'. Each of these morphemes surfaces as a $-\mathrm{CV} .{ }^{19}$ As with the "when" $-l \bar{\varepsilon}$ construction, the addition of these suffixes has no effect on the tone of the verb stem. However, as mentioned above, the SOV word order results in the Low tone replacement. When the verbal suffixes mentioned above are added to the verb stem, the tone of each of these verb suffixes is pre-assigned to the suffix, as shown below. This pattern can apply to all the inflected forms mentioned at the beginning of this section with the result shown in (41).

(41) With mode inflection -zó

\begin{tabular}{|c|c|c|c|c|}
\hline Class 1 & Class $1 \mathrm{~A}$ & Class 2 & Class $2 A$ & \\
\hline$\left.\right|_{\text {ca }} ^{\mathrm{H}}$ & $\left.\right|_{\mathrm{a}} ^{\mathrm{M} I}$ & $\left.\right|_{n I} ^{L}$ & $\left.\right|_{\partial t 1} ^{M L}$ & $U F$ \\
\hline $\mathrm{ca}$ & $\left.\right|_{\mathrm{a} j \mathrm{jI}} ^{\mathrm{M}}$ & $\left.\right|_{\mathrm{nI}} ^{\mathrm{L}}$ & $\left.\right|_{\partial \mathrm{t} i} ^{\mathrm{M}}$ & $T R$ \\
\hline$\left.\right|_{\mathrm{ca}+\mathrm{zb}} ^{\mathrm{L}}$ & $\left.\left.\right|_{\mathrm{a}} ^{\mathrm{MH}}\right|_{\mathrm{j}} ^{\mathrm{H}}+\mathrm{zJ}$ & $\left.\left.\right|_{n I} ^{L}\right|_{+z D} ^{H}$ & $\left.\right|_{\partial \mathrm{ti}+\mathrm{zo}} ^{\mathrm{M} \mathrm{L}}$ & $\begin{array}{c}+ \text { mode } \\
\text {-ź́ }\end{array}$ \\
\hline $\begin{array}{l}\text { [cà-zó] } \\
\text { 'arrived' }\end{array}$ & $\begin{array}{l}\text { [ājí-zó] } \\
\text { 'accompanied' }\end{array}$ & $\begin{array}{l}\text { [nì-zó] } \\
\text { 'went' }\end{array}$ & $\begin{array}{l}\text { [ə̄ti-zó] } \\
\text { 'leaned' }\end{array}$ & \\
\hline
\end{tabular}

4.2 $\mathrm{S}$ conjunction $\mathrm{O} \mathrm{V}$. The second major set of SOV constructions have a conjunction between the $\mathrm{S}$ and the $\mathrm{O}$. The possible conjunctions in this construction

${ }^{19}$ Only one inflectional suffix at a time may be added to a verb stem. 
type are 'sz' 'lest', '̇tiri 'when' for actions in the past that have not previously been mentioned, and 'ś' 'if' for contrary-to-fact actions.

An example of such a construction is given below in (42).
(42) gólā j̀zó
cà
rì
'lest he arrive'
3S lest arrive:conj EOC

In this construction the verb că has a rising tone. Due to the fact that this is an SOV construction, the Tone Replacement rule accounts for the Low tone on the verb. In addition, we posit a conjunction morpheme after the verb stem which consists of a floating High tone. This floating High tone associates leftwards. There is a strong tendency in Avokaya for right to left association. (See the discussion of floating low tone in section 3.1.)

In example (43) the processes involved in the tone associations for the 'lest' construction are shown.
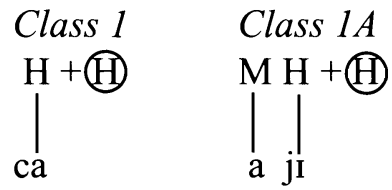

Class 2

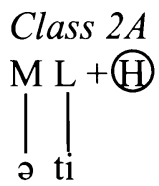

$U F$
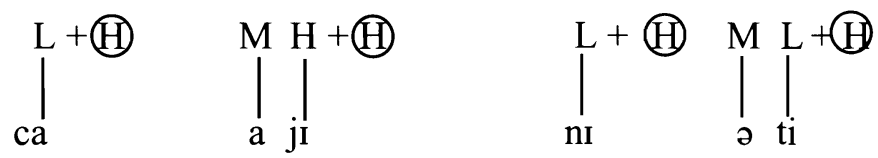

$T R$
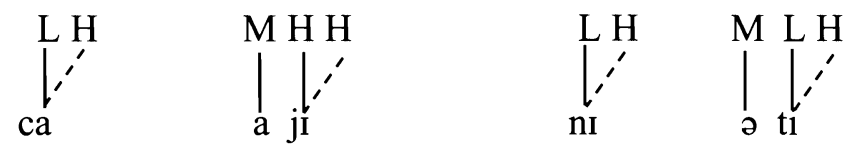

FTA

[cǎ]

[ājíi]

[ňr]

[ə̄̀ti]

'(lest) arrive' '(lest) accompany' '(lest) go' '(lest) lean'

The two High tones on $\bar{a} j I$ merge since they are the same tone, so only a level High tone results. The Low-High combination on the other verb roots surfaces as a short rising tone on the root vowel. The same pattern applies to all constructions using the conjunctions listed above.

4.3 Genitive construction and participial form. In the genitive construction (8f), the word order of the phrase is noun head $+\mathrm{O}+\mathrm{V}+k \bar{a}$. We posit a floating 
Low tone occurring before $k \bar{a}$ 'of' which will associate to the word to its left, in this case the verb. Due to the OV word order, the Tone Replacement rule operates on the monosyllabic verb roots of Class 1 and Class 2. If we look at the verbs of Classes 1,2 and 2A, there would be no need to posit the floating low tone. However the derivation of Class 1A would be incorrect without the floating low tone $\left({ }^{*} \bar{a} j \bar{I}\right)$. By positing the floating low tone, the High and Low tones combine to form a phonetic Mid tone on the short vowel, which is the correct form $(\bar{a} \bar{j} \bar{I})$.
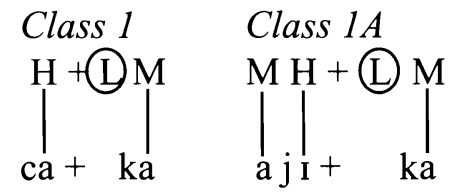

Class 2
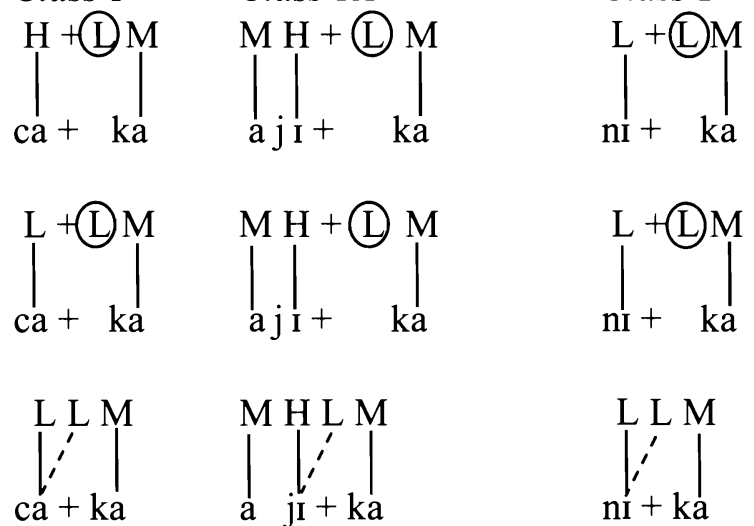

[cà kā]
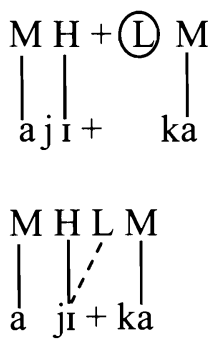

[ājī kā]
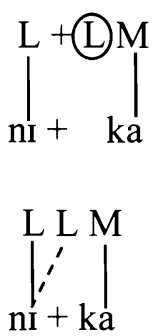

[nì kā]
Class $2 A$
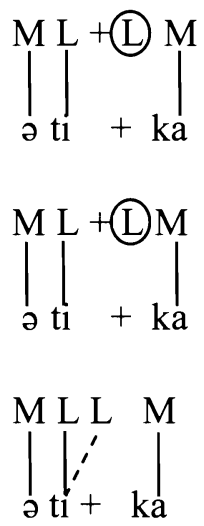

[ātì kā]

'of arriving' 'of accompanying' 'of going' 'of leaning'

For a transitive verb the participial form of the verb occurs in an OV construction. As with the genitive construction, the participle is formed by the verb stem, followed by a floating Low tone, then the whole verb stem is reduplicated, as shown below. The presence of the floating Low tone is necessary to account for the tone on the verbs of Class $1 \mathrm{~A}$.
(45) Class 1
Class $1 A$
Class 2
Class $2 A$
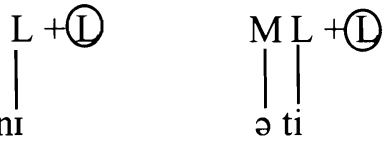
$U F$
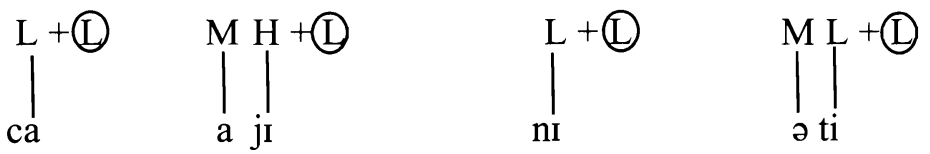
$T R$ 


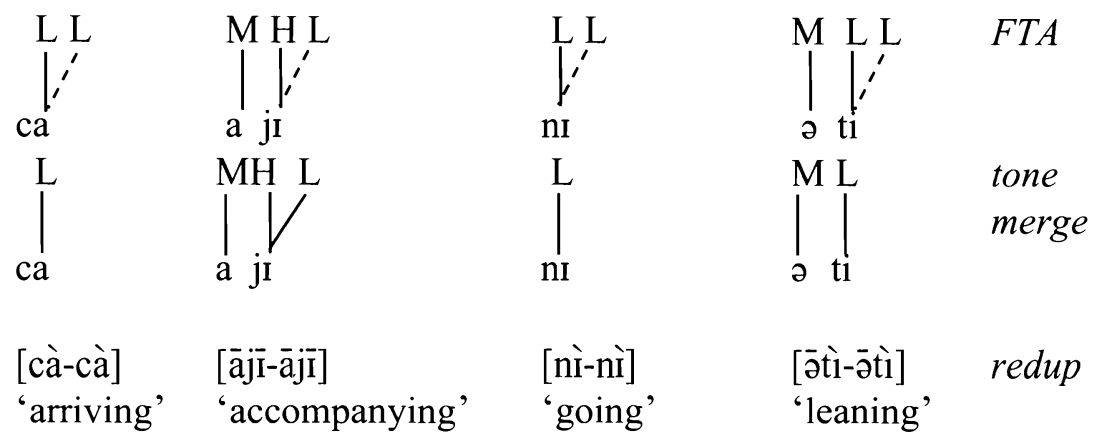

Thus all reduplicated verb forms surface with either L or M tones. No High tones occur in this construction.

\section{Conclusion.}

All tone changes in Avokaya verbs can be accounted for through a series of rules operating on the verb forms in different grammatical constructions. We have shown that derivational prefixation occurs before other processes which affect the tone of verbs. We have also shown that the processes involved in SVO constructions differ from the processes in SOV constructions, in that monosyllabic verb roots undergo the derivational process of tone replacement affecting SOV constructions before inflectional changes operate.

The ordering of the derivational processes account for why the tone patterns change when a derivational prefix is added to a Class 1 verb in an SOV construction.

$$
\begin{array}{ll}
{[[\text { cà }]-z o ́]} & \text { 'arrive (there)' } \\
{[[\bar{a}-[\text { cá }]]-z o ́]} & \text { 'arrive (here) }
\end{array}
$$

The addition of the derivational prefix changes the Class 1 verb to Class $1 \mathrm{~A}$ before the derivational process of tone replacement, which only affects Class 1 and Class 2 verbs.

Our analysis of tone replacement also accounts for why the Class 1 verb forms in the following constructions are different, even though the two suffixes are homophonous.

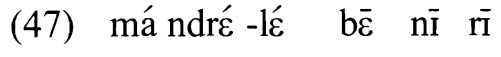
'when I saw you'
I see -when when $2 \mathrm{~S}$ EOC 

(48) má lè ánī ndrè -lé
'I want to see you'
I want $2 \mathrm{~S}$ see INFIN

Example (47) is an SVO construction, and example (48) is an SOV construction undergoing tone replacement.

We posited floating tones which account for tone changes resulting at the inflectional level. The differences in the perfective and genitive forms of the Class 1 verbs are also due to the fact that they have different word orders.

$\begin{array}{llll}\text { (49) má } & \text { gī } & \text { à'wá trá } & \text { 'I bought meat.' } \\ \text { I } & \text { buy } & \text { meat } & \text { PERF }\end{array}$

(50) làfā à'wá gì kā 'money of/for buying meat' money meat buy of

Both constructions have a floating Low tone. In example (49), the perfective construction, which is SVO, has underlying High tone in Class 1 verbs. The floating Low tone merges with this High tone to be manifested as a Mid tone. However, in example (50), the genitive form, which is SOV, has had the High tone replaced by a Low tone before the floating Low tone is applied.

Therefore previously difficult tone issues in Avokaya verbs are accounted for in our analysis. Significantly, these few rules account for all the tone changes in all the verbal constructions in Avokaya in an orderly way. (See the chart of tone changes on the following page). 
Table 1:

Summary chart of the changes

Verb Class

1

$1 A$

2

$2 A$

Root/Stem forms

$\mathrm{H}$

$\mathrm{M} \mathrm{H}$

$\mathrm{L}$

M L

Prefix Derivation

$\mathrm{H}$

M H

$\mathrm{L}$

M L

Floating Low, SVO, Perf,

HL

M HL

LL

M LL

Focus, Imper, Surface

M

$\mathrm{M} M$

L

M L

High tone on empty $V$ slot

$\mathrm{HH}$

$\mathrm{MHH}$

L H

M L H

SVO, Negative, Surface

$\mathrm{H}$

$\mathrm{M} \mathrm{H}$

LH

$\mathrm{M} \mathrm{LH}$

Derivation (SOV)

Tone Replacement

Floating High, SOV

L $\quad \mathrm{MH}$

$\mathrm{L}$

M L

$S$ Conj OV, Surface Tone

L H

$\mathrm{MHH}$

L H

$\mathrm{M} \mathrm{L} \mathrm{H}$

$\mathrm{R}$

$\mathrm{M} \mathrm{H}$

$\mathrm{R}$

M R

Floating Low, SOV

Genitive, Surface Tone

$\begin{array}{llll}\text { L L } & \text { M HL } & \text { L L } & \text { M LL } \\ \text { L } & \text { M M } & \text { L L } & \text { M L }\end{array}$

\section{REFERENCES}

Andersen, Torben. 1984. "Aspect and Word Order in Moru". Journal of African Languages and Linguistics 6: 19-34.

Callinan, Lynne. 1981. "A Preliminary Study of Avokaya Phonemes". Occasional Papers in the Study of Sudanese Languages 1: 64-73. Summer Institute of Linguistics.

Callinan, Lynne. 1986. "Sentence Constructions in Avokaya". Occasional Papers in the Study of Sudanese Languages 5:48-72. Summer Institute of Linguistics. 
Clements, George N. and Samuel Jay Keyser. 1983. CV Phonology: A Generative Theory of the Syllable. Linguistic Inquiry Monographs. Cambridge: MIT Press.

Goldsmith, John. 1990. Autosegmental and Metrical Phonology. Oxford: Blackwells.

Kilpatrick, Eileen. 1981. "Avokaya Predication”. Occasional Papers in the Study of Sudanese Languages 1: 91-109. Summer Institute of Linguistics.

Mohanan, K.P. 1986. The Theory of Lexical Phonology. Studies in Natural Languages and Linguistic Theory. Dordrecht: D. Reidel Publishing Co.

Pulleyblank, D. 1986. Tone in Lexical Phonology. Studies in Natural Languages and Linguistic Theory. Dordrecht: D. Reidel Publishing Co.

Wright, Douglas. 1995 The Verbal System of Logo (Logoti). Dallas, Texas: Graduate Institute of Applied Linguistics, M.A. thesis.

SIL, Box 750

[Received January 18, 2004

Entebbe, Uganda accepted January 20, 2005]

eileen_kilpatrick@sil.org

7614 Breckenridge Lane

Knoxville, TN 37938

leoma.gilley@suremail.org 
